\title{
Review \\ Unlocking the power of cross-species genomic analyses: identification of evolutionarily conserved breast cancer networks and validation of preclinical models
}

\author{
Christina N Bennett and Jeffrey E Green
}

Laboratory of Cancer Biology and Genetics, National Cancer Institute, Building 37, Rm 4054, 37 Convent Drive, Bethesda, MD 20892 , USA

Corresponding author: Jeffrey E Green, jegreen@nih.gov

Published: 11 September 2008

Breast Cancer Research 2008, 10:213 (doi:10.1186/bcr2125)

This article is online at http://breast-cancer-research.com/content/10/5/213

(c) 2008 BioMed Central Ltd

\begin{abstract}
The application of high-throughput genomic technologies has revealed that individual breast tumors display a variety of molecular features that require more personalized approaches to treatment. Several recent studies have demonstrated that a cross-species analytic approach provides a powerful means to filter through genetic complexity by identifying evolutionarily conserved genetic networks that are fundamental to the oncogenic process. Mousehuman tumor comparisons will provide insights into cellular origins of tumor subtypes, define interactive oncogenetic networks, identify potential novel therapeutic targets, and further validate as well as guide the selection of genetically engineered mouse models for preclinical testing.
\end{abstract}

\section{Introduction}

Within the past decade, high-throughput genomic technologies have revolutionized the study of breast cancer. Molecularly distinct tumor subtypes of human breast cancer have been identified and appear to arise from distinct progenitor lineages. These subtypes display gene expression signatures that are predictive for disease progression, prognosis, and response to therapy. Since survival rates for breast cancer have improved relatively little over the past two decades, this high-definition molecular characterization of tumor subtypes has the potential to offer new avenues for discovery of novel therapeutic targets to treat breast cancer. However, genetic complexity in diverse human populations, differences between experimental platforms, experimental designs, and improper statistical analyses [1] have contributed to the tremendous challenges of identifying the functionally most significant gene signatures and genetic networks that are critical to the oncogenic process.

One approach to improving the discovery of important genetic networks involved in cancer development and progression has been to use relevant genetically engineered mouse (GEM) models of mammary cancer in mouse-human comparisons to identify evolutionarily conserved genetic alterations shared in tumorigenesis in the two species. Recent work from several groups has applied this analytic approach to a number of cancer types, including breast cancer. This review will focus on how cross-species comparisons of gene expression, genome copy number changes, and bioinformatic analyses have improved our understanding of how particular mammary cancer models represent specific subtypes of human breast cancer. These analyses have led to an increased understanding of the cellular origins of the subtypes of breast cancer, distinctions between molecular networks in different tumor subtypes, stem cell biology, genes involved in metastatic progression, and improved selection of GEM models for preclinical testing of preventive and therapeutic strategies.

\section{Identification of evolutionarily conserved genetic alterations in breast cancer subtypes through mouse-human gene expression comparisons}

At least five molecularly distinct subtypes of breast cancer have been identified through the use of high-throughput genomic technologies [2,3]. While tumor subtypes still segregate primarily by expression of estrogen receptor (ER), p53, and ErbB2, the 'intrinsic' genetic signatures as defined by microarray studies are more informative classifiers of tumor subtypes. Importantly, predictors generated from this genomic information provide a better means of identifying patients who may not require adjuvant therapies or those patients who may not benefit from particular types of therapies, such as patients with $\mathrm{ER}^{+}$tumors that do not respond to selective ER modulators [3,4]. Additionally, mining

$\mathrm{ECM}=$ extracellular matrix; EGFR = epidermal growth factor receptor; ER = estrogen receptor; GEM = genetically engineered mouse; PR = progesterone receptor. 
genomic information will identify unique gene/pathway interactions that could be particularly useful for the development of novel, combination, and individualized therapies. However, screening and testing potentially important molecular targets in human patients remain problematic due to patient accrual, long time frames to complete trials, expense, and variability within patient populations. In this regard, GEM models show great promise in preclinical drug development, target validation, and chemoprevention. Through the use of molecular analyses employing global genomic technologies, mouse models that represent particular subtypes of human breast cancer are being identified for more rationally designed preclinical testing.

The identification of distinct expression signatures embedded in mouse mammary tumor models has helped to decipher how initiating genetic changes or carcinogens correlate with particular subtypes of human breast cancer. GEM models of mammary cancer are especially useful in this endeavor because tumors arise from defined genetic changes with relevance to human cancer, including the overexpression of Myc, ErbB2, Ras, and Wnt, and loss of suppressor gene functions for p53, Rb, BRCA1, and pTEN [5,6]. Identifying GEM mammary tumors that have expression patterns similar to human breast tumor subtypes is an important approach to finding the evolutionarily conserved mechanisms of tumor development. Additionally, it is likely that such cross-species comparisons will provide important insights into cancer progenitor lineages from which mammary tumors arise with distinct biologic properties (that is, basal versus luminal and $\mathrm{ER}^{+}$versus $\mathrm{ER}^{-}$tumors). Indeed, studies comparing gene expression signatures of GEM mammary tumor models to human breast tumors have already begun to identify GEM models that genetically recapitulate important molecular features of particular subtypes of human breast cancer $[7,8]$.

\section{Gene expression changes}

$\mathrm{Hu}$ and colleagues [9] used SAGE (serial analysis of gene expression) technology to compare gene expression levels in tumors derived from the mouse p53 null mammary transplant model and human breast tumors and found that approximately 72 transcripts were dysregulated in both. Downregulation of specific cytokines (LIF, IL6, CXCL1, and CCL2) was identified in mouse and human tumor samples as well as similar changes in the expression of genes involved in apoptosis, proliferation, and differentiation. These data highlight some of the genetic similarities between mouse and human breast cancer and support the use of GEM models as an appropriate resource for better understanding human breast cancer.

Extensive amounts of high-throughput gene expression array data have been generated for human breast tumors and similar data have been emerging for GEM mammary cancer models. Comparing array data between species has been extremely challenging for numerous technical and biologic reasons. For instance, cellular compositions of human and
GEM tumors may vary with human breast tumors often containing substantially more stromal components than the mouse tumors. Additionally, comparing data across different array platforms where gene and probe compositions are not identical raises important statistical challenges that are beyond the scope of this review but that are considered further elsewhere [10].

However, studies by Herschkowitz and colleagues [8] and our laboratory [7] have revealed that gene expression signatures associated with individual GEM models of mammary cancer express genetic profiles that are similar to particular subtypes of human of breast cancer (Table 1). Herschkowitz and colleagues [8] used gene expression profiling to compare 13 different mouse models of mammary cancer with human breast tumor data sets. Analyses of gene expression stratified GEM and DMBA-induced mammary cancer models into five groups: normal mammary gland, tumors with mesenchymal characteristics, basal/myoepithelial, luminal, and tumors with mixed characteristics.

Several GEM models display luminal features with expression of Gata3, luminal keratins $\mathrm{K} 8 / 18$, and the luminal tumordefining gene $\mathrm{XBP}_{1}$, including tumors arising from MMTVNeu, MMTV-PyMT, WAP-Myc, and WAP-Int3 models [8]. However, unlike a substantial portion of human luminal tumors, these models are ER-. This suggests that, in these mouse models, GATA3 (a gene that is coexpressed with ER in human tumors) may better identify the luminal subtype than ER expression alone. This also indicates that GATA3 expression is not sufficient to activate ER expression [11-13]. However, several GEM models develop $\mathrm{ER}^{+}$tumors, including the $\mathrm{p} 53^{\mathrm{fp} / \mathrm{fp}}$ WAP-Cre conditional knockout [14], the p53-/- transplant [15], MMTV-Wnt1 [16], and the MMTV-tTATAg-ER $\alpha$ conditional ER expression [17]. Our laboratory has demonstrated that the $\mathrm{ER}^{+}$tumors from the $\mathrm{p} 53^{\mathrm{fp} / \mathrm{fp}}$ Wap-Cre conditional knockout model segregate with luminal type $A$ human tumors (A.M. Michalowski, T. Qiu, C. Kavanaugh, E. Lee, D. Medina, X. Xu, C. Deng, J. Powell, J. Shih and J. Green, unpublished data), whereas the status of the other tumor models remains to be determined. These results raise the important issue that the method of generating a GEM model (knockout versus promoter-driven transgenic) is critical for determining which cancer progenitor cells may be targeted for transformation leading to basal or luminal phenotypes.

Another major subtype of breast cancer has been defined by the expression of basal cell characteristics, including tumors referred to as triple-negative (ER-, progesterone receptornegative $\left[\mathrm{PR}^{-}\right]$, and ErbB2-), which generally have a poor prognosis [18]. Several mouse models of mammary cancer display basal-type characteristics and cluster with human basal-type tumors, including Brca1 ${ }^{+/-}, \mathrm{p} 53^{+/-}$, irradiated [19], Brca1co/co, TgMMTV-Cre, p53+- [20], and some DMBAinduced tumors $[7,8,21]$. In particular, of the mouse models studied, the expression signature of the C3(1)Tag GEM 
Table 1

Shared genetic and genomic features between mouse models of mammary cancer and human breast tumor subtypes

\begin{tabular}{|c|c|c|c|c|}
\hline Mouse model & Shared features & Reference & $\begin{array}{l}\text { Mouse genomic } \\
\text { changes }\end{array}$ & Reference \\
\hline \multicolumn{5}{|l|}{ Luminal } \\
\hline p53 fp/fp, WAP-Cre & $\mathrm{ER}^{+}$ & $\begin{array}{l}\text { A.M. Michalowska, } \\
\text { unpublished data }\end{array}$ & & \\
\hline MMTV-Neu & $\mathrm{ER}-, \mathrm{K} 8 / \mathrm{K} 18^{+}$, and $\mathrm{XBP} 1^{+}$ & {$[7]$} & & \\
\hline MMTV-PyMT & $\mathrm{ER}^{-}, \mathrm{K} 8 / \mathrm{K} 18^{+}, \mathrm{XBP}^{+}$, and $\mathrm{GATA}^{+}$ & {$[7]$} & & \\
\hline WAP-Myc & $\mathrm{ER}^{-}, \mathrm{K} 8 / \mathrm{K}_{1} 8^{+}, \mathrm{XBP}^{+}$, and $\mathrm{GATA}^{+}$ & {$[7]$} & & \\
\hline WAP-Int3 & $\mathrm{ER}^{-}, \mathrm{K} 8 / \mathrm{K}_{1} 8^{+}$, and $\mathrm{GATA}^{+}$ & {$[7]$} & & \\
\hline \multicolumn{5}{|l|}{ Basal-like } \\
\hline С3(1)Tag & $\begin{array}{l}\mathrm{ER}^{-}, \text {Her2-, } 2^{-} \mathrm{kAS} 2 \text { amplification, } \mathrm{K}^{+}, \\
\text {proliferation signature, and poor outcome }\end{array}$ & {$[6,7]$} & Chromosome 6 & [21] \\
\hline Brca1 ${ }^{+/-}, \mathrm{p} 53^{+/-}, \mathrm{IR}$ & $\mathrm{K}^{+}$ & [7] & & \\
\hline WAP-Tag & Proliferation signature & {$[7]$} & & \\
\hline WAP-T $_{121}$ & Proliferation signature & {$[7]$} & & \\
\hline Brca1 co/co, MMTV-Cre, $\mathrm{p} 53^{+/-}$ & $\mathrm{K}^{+}$ & {$[7]$} & $\begin{array}{l}\text { Chromosomes } 4,11 \\
14,15 \text {, and } X\end{array}$ & [29] \\
\hline DMBA-induced adenocarcinoma & $\mathrm{K}^{+}$ & {$[7]$} & & \\
\hline \multicolumn{5}{|l|}{ Her2/Neu } \\
\hline $\begin{array}{l}\text { Conditional expression of endogenous } \\
\text { Neu and promoter driven-activated Neu }\end{array}$ & ErbB2 amplification & [32] & $\begin{array}{l}\text { Chromosomes } 4 \\
\text { and } 11\end{array}$ & {$[32,33]$} \\
\hline \multicolumn{5}{|l|}{ Normal breast } \\
\hline MMTV-Wnt1 & $\mathrm{K}^{+}$ & {$[7]$} & & \\
\hline \multicolumn{5}{|l|}{ Claudin-low } \\
\hline $\begin{array}{l}\text { Tumors with spindle cell morphology, } \\
\text { including Brca } 1^{\text {co/co, }} \text {, MMTV-Cre, } \\
\text { p53 } 3^{+/}, \text {DMBA-induced spindle, and } \\
\text { p53 null transplant }\end{array}$ & $\begin{array}{l}\text { Low expression: claudins } 3,4 \text {, and } 7 \text {, } \\
\text { occlucdin, and e-cadherin }\end{array}$ & {$[7]$} & & \\
\hline
\end{tabular}

ER, estrogen receptor.

model appears to most closely correlate to the human basallike subtype [8]. Because $T$ antigen binds to and inactivates tumor suppressor proteins $\mathrm{Rb}$ and $\mathrm{p} 53$, SV40-T/t-antigen expression induces an aggressive and genetically relevant oncogenic phenotype. In addition, Ki-ras amplification and overexpression seem to spontaneously occur during tumor progression in the $\mathrm{C} 3(1) / \mathrm{Tag}$ tumors and accelerate the tumor phenotype [22]. Importantly, both human basal-like and C3(1)Tag tumors have amplifications of human chromosome 12p12 (mouse chromosome 6), a region that contains Ki-ras $[8,22,23]$.

Comparing gene expression array data across species is likely to reveal additional potentially important gene signatures involved in tumorigenesis. For instance, tumor samples from the MMTV-Wnt1 mouse model express genes represented in both basal and luminal subtypes $[8,24,25]$ and cross-species analyses by Herschkowitz and colleagues [8] classified MMTV-Wnt1 mammary tumors as 'normal mammary gland'. Interestingly, other studies suggest that MMTV-Wnt1 tumors also express markers associated with progenitor cell lineages [24,25], making it a potentially useful model for isolating tumor progenitor cells.

Cross-species analyses also identified a new 'claudin-low' tumor subtype [8]. Claudin-low tumors are characterized by reduced expression of genes involved in tight junctions and cell-cell adhesion. Mouse models comprising this category include those with spindle-like morphology, including some DMBA-induced tumors, Brca1co/co, Tg MMTV-Cre, $\mathrm{p} 53^{+/-}$ tumors, and tumors from p53 null transplant model. Whether reanalysis of human breast tumor data sets uncovers the claudin-low gene signature and differentiates responses to particular treatments will be of great interest. 
Despite the ability of hierarchical clustering to indicate important specific similarities between GEM models and human subtypes of breast cancer, significant differences in gene expression exist, even between mouse and human tumors considered to represent the same subtype of mammary cancer. These distinctions must be considered when applying models to the study of human breast cancer. Nonetheless, identifying the similarities in gene expression and genetic pathways through a cross-species approach highlights important conserved molecular changes involved in oncogenesis.

\section{DNA copy number changes}

The use of gene expression profiling to identify genetic differences between normal and tumorigenic tissue is just one way to uncover how global genetic changes influence cancer development and progression. Another way to further delineate oncogenes and molecular pathways associated with tumorigenesis is through analysis of DNA copy number aberrations, using array comparative genomic hybridization.

In human breast tumors, analyses comparing genome copy number aberrations with gene expression signatures have revealed distinct genomic patterns that correlate with tumor subtype [26-28]. Bergamaschi and colleagues [26] reported that high frequency of gains/losses throughout the genome is characteristic of basal-like tumors whereas high-level DNA amplifications are distinctive for luminal B subtype tumors. ErbB2-associated tumors have characteristic amplification of the ErbB2 locus in chromosome 17, and genomic profiles of luminal $A$ tumors are associated with amplifications in chromosomes 1 and 16 [26]. A study by Adelaide and colleagues [27] compared genomic alterations of basal-like and luminal breast tumors and identified genomic changes unique to the tumor subtypes. Genomic gains of chromosomes $10 p$ and $12 p 13$ are specific to basal-like tumors, whereas gain of 11q13-14 is associated with luminal tumors [27]. High-level amplification was also reported as a feature of luminal tumors, especially in chromosome region 8p11-12 [27]. Moreover, Chin and colleagues [28] reported that patients with amplification of three regions containing known breast oncogenes 11q13(CCDN1), 17q12(ErbB2), and 20q13(ZNF217) have a poor prognosis and patients with loss of 16 q24-qtel have a good prognosis. These studies suggest that a large number of genomic aberrations, as seen in basallike and luminal B tumors, correlate with poor prognosis.

GEM models of mammary cancer have not been extensively studied for DNA copy number changes and their relationship to subtypes of breast cancer. However, DNA copy number changes have been assessed in a few GEM models of mammary cancer and have revealed evolutionarily conserved syntenic chromosomal changes [29-31].

Weaver and colleagues [31] reported that chromosomal instability, in a pattern common to BRCA-associated breast tumors, is also present in a BRCA-deficient mouse model for mammary cancer. Chromosomal gains/losses were found in genomic regions for $\mathrm{c}-\mathrm{Myc}, \mathrm{Rb} 1$, and genes distal to ErbB2, suggesting the influence of these oncogenes on BRCAassociated tumor development. Weaver and colleagues [29] also reported that MMTV-myc mammary tumors have genomic changes that are relevant to human mammary tumors, including loss of whole chromosome 4, which contains a region syntenic to human 1p31-36 and is often lost in human breast tumors. Thus, distinctions in DNA copy number changes may be important in relating GEM models to subtypes of human breast cancer.

Interestingly, GEM models with p53 loss do not demonstrate the same degree of genomic instability as observed in human breast tumors [29,32,33]. For example, tumor latency is reduced when the WAP-T $_{121}$ mouse model (a mammaryspecific transgenic model in which a fragment of SV40 $\mathrm{T}$-antigen protein binds to and inactivates $\mathrm{pRb}$ ) is crossed to p53 heterozygous mice. However, analyses of genomic

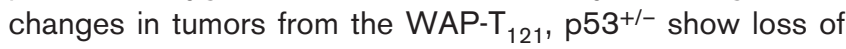
wildtype p53 allele at chromosome 11 but with minimal increases in other DNA aberrations. Thus, DNA copy number changes may reflect the mechanism of oncogenesis employed in the design of the GEM model. For example, Andrechek and colleagues [34] reported that the GEM mammary tumor model induced by endogenous promoterdriven ErbB2 expression induces mammary tumors with DNA amplification similar to human ErbB2-amplified breast tumors [30]. Such genomic changes are not found in MMTV-ErbB2 mice, suggesting that the ErbB2 model, developed using the endogenous ErbB2 promoter, is more representative of human ErbB2-amplified breast tumors in this regard [30,35]. This difference may be associated with the fact that high expression of oncogenes, as seen using the MMTV promoter, may require fewer genomic alterations for tumorigenesis than present in models based upon endogenous promoter-driven gene expression or loss of suppressor gene functions, especially those involved in genome stability such as p53 and BRCA1. Overall, it appears that DNA copy number changes are less prevalent in the oncogene-driven GEM models compared with models in which genetic alterations lead to genomic instability [36]. This distinction in rate of tumor progression and accumulation of genetic mutations between GEM models and human breast tumors is important and should be considered when choosing GEM models to represent subtypes of human breast cancer.

\section{Applying mouse-human gene expression analyses to identify genetic markers of metastatic potential and poor prognosis}

Breast cancer metastasis is the major risk factor for poor prognosis and accounts for more than $90 \%$ of patient mortality. However, little is understood about why some patients develop metastatic disease whereas other patients do not. The study of molecular mechanisms involved in the 
metastatic process is limited by the difficulty in obtaining multiple tissue samples from the same patient over the course of disease, particularly once metastases have developed. GEM models, though, offer important advantages in studying the metastatic process, including large sample number and the ability to study tumor progression by collecting samples at distinct tumor stages. While existing models of mammary cancer metastases are limited in GEM systems, several models have been extremely informative and have shed important insights into genetic factors that are involved in human metastases.

\section{Genetic signatures of metastasis}

Gene expression profiles have led to the discovery of predictors that improve the identification of patients at high risk of developing metastatic disease. Importantly, such predictors can be gleaned from gene expression measured in primary breast tumors, indicating that metastatic propensity is predetermined in large part by genetic changes pre-existing in the primary tumor [37-41].

$\mathrm{Ma}$ and colleagues [42], using laser capture microscopy to separate cells from pathologically distinct stages of tumor progression, determined that tumor cells have very similar gene expression profiles within a patient sample set. Thus, tumor cells isolated from atypical ductal hyperplasia, ductal carcinoma in situ, and invasive ductal carcinoma appear clonal and do not exhibit large changes in gene expression during tumor progression [42]. Similar findings were also demonstrated in the $\mathrm{C} 3(1) / \mathrm{Tag}$ model of mammary cancer [43] and in the PyMT mammary intraepithelial neoplasiaoutgrowth (MIN-O) transplant model [44]. In both mouse models, analysis of early lesions versus invasive carcinoma revealed relatively few genetic changes with mammary tumor progression [43,44]. Indeed, the dynamics of gene expression changes during tumor progression appear similar in GEM models and human cancer.

The fact that relatively few expression changes are observed between preinvasive and invasive cancer suggests that nongenetic factors, perhaps influenced by the microenvironment $[45,46]$, are instrumental for tumor progression, metastases, and the regulation of the dormant-to-proliferative switch of disseminated tumor cells in disease recurrence [47]. In fact, many genes identified in signatures related to human breast cancer metastases are associated with proteins found in the extracellular matrix (ECM) [38,39,48-50], suggesting that the ECM may strongly influence metastatic cell survival and growth. Several ECM genes, including Col1a2, Col1a1, Fbn1, MMP-2, Sparc, laminino5, and tenascin- $C$, have similarly been identified in expression signatures related to metastases in mouse mammary cancer models [51-54]. Moreover, it has been reported that gene expression profiling using 278 ECM-related genes can predict clinical outcome and recurrence in patients with invasive breast tumors [55], suggesting that the composition of ECM in the primary tumor is a highly relevant factor of metastasis.

Tumor progression is also affected by paracrine signaling from neighboring fibroblasts and myoepithelial cells. Allinen and colleagues [46] identified gene expression changes within the various cell types comprising normal, ductal carcinoma in situ, and invasive breast cancer. Interestingly, tumor myofibroblasts and tumor myoepithelial cells overexpress CXCL14 and CXCL12 chemokines. Receptors for these chemokines are found on epithelial cells, allowing for crosstalk between cell types to promote tumor proliferation and invasion. Such findings suggest that tumor progression is associated with both intrinsic changes within the tumor cells as well as through stimuli from cells within the local environment. It will be interesting to compare the results of similar studies performed using various GEM models to further uncover how cross-talk between epithelial cells and surrounding stromal cells is altered by particular genetic mutations induced in the epithelial tumor cells.

Gene expression signatures in primary breast tumors also appear to contain information regarding organ specificity of metastatic dissemination. Work from the laboratory of Massague and colleagues [48,56] has identified gene expression signatures in subpopulations of primary human breast tumor cells that predict the organ site for distant metastasis when implanted into immunocompromised mice. Whether these genetic signatures are universal predictors of future metastases for all primary breast tumors will be of great interest.

\section{Genetic modifiers of metastasis}

One major finding revealed through GEM studies has been the demonstration that the host genetic background can greatly alter the incidence of metastases. When MMTV-PyMT mice were crossed into different background strains, a great range of metastatic propensities were observed between the F1 hybrids [51]. Importantly, 16 out of 17 genes identified in a human predictor of epithelial metastases were similarly dysregulated in tumors from the mice with the high metastatic propensity [38,51]. This suggests that similar molecular mechanisms may be involved in human and mouse metastatic disease and that genetic modifiers may be critical determinants for whether metastases will occur in human patients $[51,52,54,57]$. These observations raise the important concept that, depending upon the complement of modifier genes, particular patients may be predisposed or resistant to metastatic disease.

GEM models may also serve to further understand the roles of prometastatic genes in tumor dissemination and growth. For example, MMTV-myc mice predictably develop mammary tumors with a low incidence of lung metastases [58,59]. We have recently shown that, when these mice are crossed with MMTV-VEGF mice, a significant increase in lung metastases 
is observed [53]. Comparisons of gene expression profiles from primary tumors of MMTV-myc versus compound MMTVmyc, MMTV-VEGF mice demonstrated that VEGF induced a significant number of genes, many of which were implicated in metastases from human breast cancer studies, including tenascin- $C$, MMP-2, collagen-6-A1, mannosidase- $\alpha-1 A$, and HLA-DPA1 [49,53]. Interestingly, many of the dysregulated genes are functionally involved in components of the ECM. Thus, comparisons of expression data between mouse and human tumors are helping to identify new genes potentially involved in the metastatic process and validating others that have been found through different experimental approaches.

\section{Stem cells and cancer}

The role of cancer stem cells in tumor growth and metastasis has become an area of great interest in the field with important implications for tumor treatment and resistance [60]. GEM models can be used to enrich for tumor progenitor cells and study molecular distinctions between progenitor and whole tumor cell populations. Analyses of several GEM mammary cancer models suggested that tumors from certain models may be enriched for cells with stem cell characteristics compared with other models. $\mathrm{Li}$ and colleagues [24,25] demonstrated that MMTV-Wnt1 tumors express markers associated with progenitor cell lineages, including keratin-6, Sca-1, CD44, and CD24, making it a potentially useful model for isolating tumor stem cells. Recent work from Zhang and colleagues [61] has determined that a gene expression signature for a tumorinitiating cell population from a p53 mammary tumor knockout model is enriched for genes involved in DNA damage response and repair as well as for genes involved in epigenetic regulation previously shown to be critical for stem cell self-renewal. This model suggests that identification of biomarkers for cancer stem cells may help to identify the population of cells that resist chemotherapy and are metastatic with important implications for understanding and overcoming resistance to chemotherapies for human tumors.

Interestingly, based upon the hypothesis that cancer stem cells are enriched in metastatic tumors [62], Glinsky and colleagues [63] identified a metastasis signature, through comparison of primary and metastatic prostate tumors isolated from transgenic mice that express SV40 T/t antigen, and a stem cell signature, through evaluation of human peripheral nervous system cells on a BMl-1+ and $\mathrm{BMl}-1^{-}$ genetic background $[64,65]$. Integration of the two signatures revealed an 11-gene predictor that correlates with poor prognosis in several human cancer data sets, including breast cancer patients.

\section{Use of cross-species analyses for identification of novel therapeutic targets and selection of genetically engineered mouse models for preclinical testing}

Standard practices for the diagnosis and characterization of breast cancer rely on anatomical, histological, and immuno- histochemical features of the tumor. In particular, determining expression of ER, PR, and Her2 remains critical in tumor classification and choosing optimal therapies. Too often, however, existing treatments fail. Therefore, additional molecular characterizations of breast tumors are required to further dissect critical molecular pathways that determine the biology and therapeutic response of tumors. The newer generation of GEM models more accurately recapitulate genetic changes in human breast cancer and therefore should be valuable in drug target validation and preclinical testing. Additionally, as conserved cancer genetic networks are identified through cross-species analyses of gene expression, potential new targets for therapy may be uncovered. Ideally, using these GEM models to identify chemopreventive agents that may reduce cancer risk or disease progression will be another tremendous application of sophisticated models for translational research [66]. Such approaches, however, require significant validation to demonstrate that GEM models have predictive value for treating human breast cancer.

\section{Genetically engineered mouse models for drug target validation}

GEM models with specific genetic alterations have been used to test therapies that target specific genes or related pathways. For instance, drugs that inhibit ErbB2 function or vaccines targeting the overexpression of ErbB2 have been tested in GEM models that overexpress ErbB2 [67,68]. Other biologic processes, such as angiogenesis, have been successfully targeted in GEM models $[69,70]$. More recently, the conditional expression of oncogenes in transgenic animals has been used to determine whether the expression of particular oncogenes must be sustained to maintain tumor viability or whether cancer cells develop other compensatory mechanisms for tumor survival [71-76]. If a tumor requires the continued expression of the oncogene, the gene or pathway would be a high-priority therapeutic target.

Several papers report that turning off the oncogene that initiated cancer in transgenic mice ( $\mathrm{Neu}, \mathrm{Myc}$, and Wnt-1) following the emergence of primary or metastatic tumors results in the rapid regression of tumors at both sites $[71,74,75]$. This may indicate that these oncogene-driven models do not develop significant genome instability and secondary genetic alterations. However, mammary and metastatic tumors often recur in these mice independently of the expression of the initiating oncogene, suggesting that some cells have gained additional genetic alterations. These findings suggest that regulation of initiating mutations may not be sufficient to control tumorigenesis. This is likely due to accumulation of additional alterations involving other signaling pathways, including those controlled by $\mathrm{p} 53$, K-ras2, and H-Ras1 [74,76], suggesting that cancer therapies may require the targeting of multiple genes or pathways. Cross-species comparisons of genomic changes in mammary cancer may further enhance the discovery of such additional cancer targets. Many GEM models, however, 
exhibit a relatively long latency for tumor development and incur a considerable expense, making them unsuitable for rapid high-throughput testing of therapies. The application of an adapted method for tumor transplantation may be used to take advantage of the precise genetic alterations designed into the GEM models, but in a highly reproducible and relatively rapid fashion [77].

\section{New drug target identification using gene networks}

Comparisons between high-throughput genomic analyses of inducible GEM models of mammary cancer and human breast tumors will provide further molecular validation of specific models as representative of certain subtypes of human breast cancer $[5,7,8]$. These analyses will then identify molecular targets dysregulated in GEM models that can be tested for therapeutic effects and potentially translated to human trials.

For instance, a more thorough comparison of genetic signatures within several SV40 Tag GEM models of cancer revealed a conserved SV40-T/t-antigen tumor signature [7]. This 120 -gene signature appears to be relatively specific to molecular dysregulation induced by SV40-T/t antigen and is less represented in mammary tumors induced by other oncogenic mechanisms, although other models with basallike characteristics - Brca1 ${ }^{\mathrm{co} / \mathrm{co}}$, MMTV-Cre, $\mathrm{p} 53^{+/-}$, and p53 $3^{\mathrm{fl} / \mathrm{fl}}$ MMTV-Cre - overlap in significant aspects of this signature [7]. Many of the genes represented in the T/tantigen signature are functionally involved with cell cycle regulation, proliferation, cell replication, DNA maintenance and repair, and apoptosis. When analyzed for reported functional relationships between the genes, 85 of 120 named genes within the Tag signature formed highly integrated networks with nodes centered on $\mathrm{p} 53, \mathrm{Rb}$, and myc, with additional subnetworks related to BRCA1 and apoptosis genes. Importantly, cross-species analysis of the SV4O gene signature with gene expression data from human breast tumors demonstrated that the T/t-antigen signature identified patients with basal-type tumors and poor prognosis.

Since the T/t-antigen signature identified about twice as many genes related to the functional categories discussed above as reported in studies limited to human expression analyses [7], genomic information from mouse models can clearly augment our molecular understanding of cancer networks. This will likely be especially important in expanding the discovery of potential therapeutic targets, particularly for treatment of basal-like triple-negative breast tumors. Identifying individual or combination therapies that can inhibit this subtype of breast cancer using the C3(1)/Tag or other models with basal-type characteristics - $\mathrm{BRCA} 1^{-/-}, \mathrm{p} 53^{+/-}$,

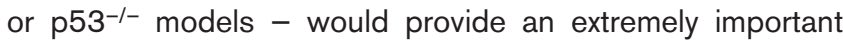
advance in treating this aggressive form of the disease.

Hoadley and colleagues [78] recently observed that epidermal growth factor receptor (EGFR) is overexpressed in basal-type breast tumors. Studies of whether EGFR inhibitors, perhaps in combination with other drugs, might be efficacious against basal-type breast tumors could be studied in appropriate GEM models representing this subtype of breast cancer. Similarly, the $p 53^{\mathrm{fl} / \mathrm{fl}}$ MMTV-Cre model for $\mathrm{ER}^{+}$ mammary tumors, which appears to represent the luminal type A subtype of breast cancer (A.M. Michalowski, unpublished data), may be useful for testing novel therapies for this subtype of breast cancer. Additional distinctions for other GEM models will emerge as such comparative crossspecies studies are expanded.

\section{Chemoprevention}

More focus will be given to GEM models for chemoprevention research, especially since they have demonstrated their utility in testing preventative agents with translational potential for several tumors [79-83]. GEM models of mammary cancer that have defined courses of tumor progression are excellent choices for prevention studies. For example, treatment with rexinoids, which are vitamin A analogs, prior to lesion development inhibits development of malignant and premalignant mammary lesions in MMTVErbB2 mice [81,82]. Moreover, genes associated with rexinoid treatment, including Id-1, IGFBP-6, and SCD-1, have been identified by gene expression array analyses [84]. Such data will be integral in identifying the genetic factors that may be critical in preventing tumor progression and applicable to human chemoprevention.

\section{Conclusion}

Through cross-species genomic studies, GEM models of mammary cancer offer promising new approaches to study mechanisms of oncogenesis, including the cellular origins of tumors that appear to represent different lineages, the roles of tumor progenitor cells, and genomic changes involved in metastases and resistance to chemotherapies. Genomic data from the mouse can serve as an important filter for human data to help identify important changes at the level of DNA copy number, gene transcription, and higher-order integrated genetic networks including microRNAs. These approaches have only recently been applied to analyses of breast cancer [85]. As progress is made in this area, novel targets for therapy or combination therapies will be uncovered and appropriate GEM models will be used for preclinical testing to greatly accelerate translational research for breast cancer.

\section{Competing interests}

The authors declare that they have no competing interests.

\section{References}

1. Dupuy A, Simon RM: Critical review of published microarray studies for cancer outcome and guidelines on statistical analysis and reporting. J Natl Cancer Inst 2007, 99:147-157.

2. Perou CM, Sorlie T, Eisen MB, van de Rijn M, Jeffrey SS, Rees CA, Pollack JR, Ross DT, Johnsen H, Akslen LA, Fluge O, Pergamenschikov A, Williams C, Zhu SX, Lønning PE, Børresen-Dale $A L$, Brown PO, Botstein D: Molecular portraits of human breast tumours. Nature 2000, 406:747-752. 
3. Sorlie T, Perou CM, Tibshirani R, Aas T, Geisler S, Johnsen H, Hastie T, Eisen MB, van de Rijn M, Jeffrey SS, Thorsen T, Quist H, Matese JC, Brown PO, Botstein D, Eystein Lønning P, BørresenDale AL: Gene expression patterns of breast carcinomas distinguish tumor subclasses with clinical implications. Proc Natl Acad Sci U S A 2001, 98:10869-10874.

4. van de Vijver MJ, He YD, van't Veer LJ, Dai H, Hart AA, Voskuil DW, Schreiber GJ, Peterse JL, Roberts C, Marton MJ, Parrish M, Atsma D, Witteveen A, Glas A, Delahaye L, van der Velde T, Bartelink H, Rodenhuis S, Rutgers ET, Friend SH, Bernards R: A gene-expression signature as a predictor of survival in breast cancer. N Engl J Med 2002, 347:1999-2009.

5. Desai KV, Xiao N, Wang W, Gangi L, Greene J, Powell Jl, Dickson R, Furth P, Hunter K, Kucherlapati R, Simon R, Liu ET, Green JE: Initiating oncogenic event determines gene-expression patterns of human breast cancer models. Proc Natl Acad Sci U S A 2002, 99:6967-6972.

6. Vargo-Gogola T, Rosen JM: Modelling breast cancer: one size does not fit all. Nat Rev Cancer 2007, 7:659-672.

7. Deeb KK, Michalowska AM, Yoon CY, Krummey SM, Hoenerhoff MJ, Kavanaugh C, Li MC, Demayo FJ, Linnoila I, Deng CX, Lee EY, Medina D, Shih JH, Green JE: Identification of an integrated SV40 $\mathrm{T} / \mathrm{t}$-antigen cancer signature in aggressive human breast, prostate, and lung carcinomas with poor prognosis. Cancer Res 2007, 67:8065-8080.

8. Herschkowitz JI, Simin K, Weigman VJ, Mikaelian I, Usary J, Hu Z, Rasmussen KE, Jones LP, Assefnia S, Chandrasekharan S, Backlund MG, Yin Y, Khramtsov Al, Bastein R, Quackenbush J, Glazer RI, Brown PH, Green JE, Kopelovich L, Furth PA, Palazzo JP, Olopade OI, Bernard PS, Churchill GA, Van Dyke T, Perou CM: Identification of conserved gene expression features between murine mammary carcinoma models and human breast tumors. Genome Biol 2007, 8:R76.

9. Hu Y, Sun H, Drake J, Kittrell F, Abba MC, Deng L, Gaddis S, Sahin A, Baggerly K, Medina D, Aldaz CM: From mice to humans: identification of commonly deregulated genes in mammary cancer via comparative SAGE studies. Cancer Res 2004, 64:7748-7755.

10. Hoenerhoff MJ, Michalowski AM, Qiu TH, Green JE: Bioinformatics approaches to the analysis of the transcriptome of animal models of cancer. In Bioinformatics in Cancer and Cancer Therapy. Chapter 4. Totowa NJ: Humana Press; 2009.

11. Eeckhoute J, Keeton EK, Lupien M, Krum SA, Carroll JS, Brown M: Positive cross-regulatory loop ties GATA-3 to estrogen receptor alpha expression in breast cancer. Cancer Res 2007, 67:6477-6483

12. Asselin-Labat ML, Sutherland KD, Barker H, Thomas R, Shackleton M, Forrest NC, Hartley L, Robb L, Grosveld FG, van der Wees J, Lindeman GJ, Visvader JE: Gata-3 is an essential regulator of mammary-gland morphogenesis and luminal-cell differentiation. Nat Cell Biol 2007, 9:201-209.

13. Kouros-Mehr H, Slorach EM, Sternlicht MD, Werb Z: GATA-3 maintains the differentiation of the luminal cell fate in the mammary gland. Cell 2006, 127:1041-1055.

14. Lin SC, Lee KF, Nikitin AY, Hilsenbeck SG, Cardiff RD, Li A, Kang KW, Frank SA, Lee WH, Lee EY: Somatic mutation of p53 leads to estrogen receptor alpha-positive and -negative mouse mammary tumors with high frequency of metastasis. Cancer Res 2004, 64:3525-3532.

15. Jerry DJ, Kittrell FS, Kuperwasser C, Laucirica R, Dickinson ES, Bonilla PJ, Butel JS, Medina D: A mammary-specific model demonstrates the role of the p53 tumor suppressor gene in tumor development. Oncogene 2000, 19:1052-1058.

16. Zhang X, Podsypanina K, Huang S, Mohsin SK, Chamness GC, Hatsell S, Cowin P, Schiff R, Li Y: Estrogen receptor positivity in mammary tumors of Wnt-1 transgenic mice is influenced by collaborating oncogenic mutations. Oncogene 2005, 24:4220-4231.

17. Tilli MT, Frech MS, Steed ME, Hruska KS, Johnson MD, Flaws JA, Furth PA: Introduction of estrogen receptor-alpha into the tTA/TAg conditional mouse model precipitates the development of estrogen-responsive mammary adenocarcinoma. Am J Pathol 2003, 163:1713-1719.

18. Cleator S, Heller W, Coombes RC: Triple-negative breast cancer: therapeutic options. Lancet Oncol 2007, 8:235-244.

19. Cressman VL, Backlund DC, Hicks EM, Gowen LC, Godfrey V, Koller BH: Mammary tumor formation in p53- and BRCA1-deficient mice. Cell Growth Differ 1999, 10:1-10.
20. Xu X, Wagner KU, Larson D, Weaver Z, Li C, Ried T, Hennighausen L, Wynshaw-Boris A, Deng CX: Conditional mutation of Brca1 in mammary epithelial cells results in blunted ductal morphogenesis and tumour formation. Nat Genet 1999, 22: 37-43.

21. Yin Y, Bai R, Russell RG, Beildeck ME, Xie Z, Kopelovich L, Glazer Rl: Characterization of medroxyprogesterone and DMBA-induced multilineage mammary tumors by gene expression profiling. Mol Carcinog 2005, 44:42-50.

22. Liu ML, Shibata MA, Von Lintig FC, Wang W, Cassenaer S, Boss GR, Green JE: Haploid loss of Ki-ras delays mammary tumor progression in C3 (1)/SV40 Tag transgenic mice. Oncogene 2001, 20:2044-2049.

23. Green JE, Shibata MA, Yoshidome K, Liu ML, Jorcyk C, Anver MR Wigginton J, Wiltrout R, Shibata E, Kaczmarczyk S, Wang W, Liu ZY, Calvo A, Couldrey C: The C3(1)/SV40 T-antigen transgenic mouse model of mammary cancer: ductal epithelial cell targeting with multistage progression to carcinoma. Oncogene 2000, 19:1020-1027.

24. Huang S, Chen Y, Podsypanina K, Li Y: Comparison of expression profiles of metastatic versus primary mammary tumors in MMTV-Wnt-1 and MMTV-Neu transgenic mice. Neoplasia 2008, 10:118-124.

25. Li Y, Welm B, Podsypanina K, Huang S, Chamorro M, Zhang X, Rowlands T, Egeblad M, Cowin P, Werb Z, Tan LK, Rosen JM, Varmus HE: Evidence that transgenes encoding components of the Wnt signaling pathway preferentially induce mammary cancers from progenitor cells. Proc Natl Acad Sci U S A 2003, 100:15853-15858.

26. Bergamaschi A, Kim YH, Wang P, Sorlie T, Hernandez-Boussard $T$, Lonning PE, Tibshirani R, Borresen-Dale AL, Pollack JR: Distinct patterns of DNA copy number alteration are associated with different clinicopathological features and gene-expression subtypes of breast cancer. Genes Chromosomes Cancer 2006, 45:1033-1040.

27. Adelaide J, Finetti P, Bekhouche I, Repellini L, Geneix J, Sircoulomb F, Charafe-Jauffret E, Cervera N, Desplans J, Parzy D, Schoenmakers E, Viens P, Jacquemier J, Birnbaum D, Bertucci F, Chaffanet $M$ : Integrated profiling of basal and luminal breast cancers. Cancer Res 2007, 67:11565-11575.

28. Chin K, DeVries S, Fridlyand J, Spellman PT, Roydasgupta R, Kuo WL, Lapuk A, Neve RM, Qian Z, Ryder T, Chen F, Feiler H, Tokuyasu T, Kingsley C, Dairkee S, Meng Z, Chew K, Pinkel D, Jain A, Ljung BM, Esserman L, Albertson DG, Waldman FM, Gray JW: Genomic and transcriptional aberrations linked to breast cancer pathophysiologies. Cancer Cell 2006, 10:529-541.

29. Weaver ZA, McCormack SJ, Liyanage M, du Manoir S, Coleman $A$, Schrock E, Dickson RB, Ried T: A recurring pattern of chromosomal aberrations in mammary gland tumors of MMTVcmyc transgenic mice. Genes Chromosomes Cancer 1999, 25: 251-260.

30. Montagna C, Andrechek ER, Padilla-Nash H, Muller WJ, Ried T: Centrosome abnormalities, recurring deletions of chromosome 4, and genomic amplification of HER2/neu define mouse mammary gland adenocarcinomas induced by mutant HER2/neu. Oncogene 2002, 21:890-898.

31. Weaver Z, Montagna C, Xu X, Howard T, Gadina M, Brodie SG, Deng CX, Ried T: Mammary tumors in mice conditionally mutant for Brca1 exhibit gross genomic instability and centrosome amplification yet display a recurring distribution of genomic imbalances that is similar to human breast cancer. Oncogene 2002, 21:5097-5107.

32. McCormack SJ, Weaver Z, Deming S, Natarajan G, Torri J, Johnson MD, Liyanage M, Ried T, Dickson RB: Myc/p53 interactions in transgenic mouse mammary development, tumorigenesis and chromosomal instability. Oncogene 1998, 16: 2755-2766.

33. Simin K, Wu H, Lu L, Pinkel D, Albertson D, Cardiff RD, Van Dyke $\mathrm{T}$ : $\mathrm{pRb}$ inactivation in mammary cells reveals common mechanisms for tumor initiation and progression in divergent epithelia. PLoS Biol 2004, 2:E22.

34. Andrechek ER, Hardy WR, Siegel PM, Rudnicki MA, Cardiff RD, Muller WJ: Amplification of the neu/erbB-2 oncogene in a mouse model of mammary tumorigenesis. Proc Natl Acad Sci U S A 2000, 97:3444-3449.

35. Hodgson JG, Malek T, Bornstein S, Hariono S, Ginzinger DG, Muller WJ, Gray JW: Copy number aberrations in mouse 
breast tumors reveal loci and genes important in tumorigenic receptor tyrosine kinase signaling. Cancer Res 2005, 65:96959704.

36. Barkan D, Montagna C, Reid T, Green JE: Mammay gland cancer. In Mouse Models of Human Cancer. Edited by Holland EC. Hoboken: John Wiley \& Sons, Inc.; 2004:103-131.

37. van't Veer LJ, Dai H, van de Vijver MJ, He YD, Hart AA, Mao M, Peterse HL, van der Kooy K, Marton MJ, Witteveen AT, Schreiber GJ, Kerkhoven RM, Roberts C, Linsley PS, Bernards R, Friend $\mathrm{SH}$ : Gene expression profiling predicts clinical outcome of breast cancer. Nature 2002, 415:530-536.

38. Ramaswamy S, Ross KN, Lander ES, Golub TR: A molecular signature of metastasis in primary solid tumors. Nat Genet 2003, 33:49-54.

39. Weigelt B, Hu Z, He X, Livasy C, Carey LA, Ewend MG, Glas AM, Perou CM, van't Veer LJ: Molecular portraits and 70-gene prognosis signature are preserved throughout the metastatic process of breast cancer. Cancer Res 2005, 65:9155-9158.

40. Porter DA, Krop IE, Nasser S, Sgroi D, Kaelin CM, Marks JR, Riggins G, Polyak K: A SAGE (serial analysis of gene expression) view of breast tumor progression. Cancer Res 2001, 61: 5697-5702.

41. Yao J, Weremowicz S, Feng B, Gentleman RC, Marks JR, Gelman $\mathrm{R}$, Brennan $\mathrm{C}$, Polyak K: Combined cDNA array comparative genomic hybridization and serial analysis of gene expression analysis of breast tumor progression. Cancer Res 2006, 66: 4065-4078.

42. Ma XJ, Salunga R, Tuggle JT, Gaudet J, Enright E, McQuary P, Payette T, Pistone M, Stecker K, Zhang BM, Zhou YX, Varnholt H, Smith B, Gadd M, Chatfield E, Kessler J, Baer TM, Erlander MG, Sgroi DC: Gene expression profiles of human breast cancer progression. Proc Natl Acad Sci U S A 2003, 100:5974-5979.

43. Ye Y, Qiu TH, Kavanaugh C, Green JE: Molecular mechanisms of breast cancer progression: lessons from mouse mammary cancer models and gene expression profiling. Breast Dis 2004, 19:69-82.

44. Namba R, Maglione JE, Davis RR, Baron CA, Liu S, Carmack CE, Young LJ, Borowsky AD, Cardiff RD, Gregg JP: Heterogeneity of mammary lesions represent molecular differences. BMC Cancer 2006, 6:275.

45. Hu M, Yao J, Carroll DK, Weremowicz S, Chen H, Carrasco D, Richardson A, Violette S, Nikolskaya T, Nikolsky Y, Bauerlein EL, Hahn WC, Gelman RS, Allred C, Bissell MJ, Schnitt S, Polyak K: Regulation of in situ to invasive breast carcinoma transition. Cancer Cell 2008, 13:394-406.

46. Allinen M, Beroukhim R, Cai L, Brennan C, Lahti-Domenici J, Huang $\mathrm{H}$, Porter D, Hu M, Chin L, Richardson A, Schnitt S, Sellers WR, Polyak K: Molecular characterization of the tumor microenvironment in breast cancer. Cancer Cell 2004, 6:1732.

47. Schedin $\mathrm{P}$, Elias A: Multistep tumorigenesis and the microenvironment. Breast Cancer Res 2004, 6:93-101.

48. Minn AJ, Gupta GP, Siegel PM, Bos PD, Shu W, Giri DD, Viale A Olshen AB, Gerald WL, Massague J: Genes that mediate breast cancer metastasis to lung. Nature 2005, 436:518-524.

49. Minn AJ, Kang Y, Serganova I, Gupta GP, Giri DD, Doubrovin M, Ponomarev V, Gerald WL, Blasberg R, Massague J: Distinct organ-specific metastatic potential of individual breast cancer cells and primary tumors. $J$ Clin Invest 2005, 115:44-55.

50. Eckhardt BL, Parker BS, van Laar RK, Restall CM, Natoli AL, Tavaria MD, Stanley KL, Sloan EK, Moseley JM, Anderson RL: Genomic analysis of a spontaneous model of breast cancer metastasis to bone reveals a role for the extracellular matrix. Mol Cancer Res 2005, 3:1-13.

51. Qiu TH, Chandramouli GV, Hunter KW, Alkharouf NW, Green JE, Liu ET: Global expression profiling identifies signatures of tumor virulence in MMTV-PyMT-transgenic mice: correlation to human disease. Cancer Res 2004, 64:5973-5981.

52. Yang H, Yu LR, Yi M, Lucas DA, Lukes L, Lancaster M, Chan KC, Issaq HJ, Stephens RM, Conrads TP, Veenstra TD, Hunter KW: Parallel analysis of transcript and translation profiles: identification of metastasis-related signal pathways differentially regulated by drug and genetic modifications. J Proteome Res 2006, 5:1555-1567.

53. Calvo A, Catena R, Noble MS, Carbott D, Gil-Bazo I, GonzalezMoreno O, Huh J-I, Sharp R, Qiu T-H, Anver MR, Merlino G, Dickson RB, Johnson MD, Green JE: Identification of VEGF-reg- ulated genes associated with increased lung metastatic potential: functional involvement of tenascin-C in tumor growth and lung metastatis. Oncogene 2008, May 26. [Epub ahead of print]

54. Crawford NP, Walker RC, Lukes L, Officewala JS, Williams RW, Hunter KW: The Diasporin Pathway: a tumor progressionrelated transcriptional network that predicts breast cancer survival. Clin Exp Metastasis 2008, 25:357-369.

55. Bergamaschi A, Tagliabue E, Sorlie T, Naume B, Triulzi T, Orlandi $R$, Russnes HG, Nesland JM, Tammi R, Auvinen P, Kosma VM, Ménard S, Børresen-Dale AL: Extracellular matrix signature identifies breast cancer subgroups with different clinical outcome. J Pathol 2008, 214:357-367.

56. Kang Y, Siegel PM, Shu W, Drobnjak M, Kakonen SM, CordonCardo C, Guise TA, Massague J: A multigenic program mediating breast cancer metastasis to bone. Cancer Cell 2003, 3: 537-549.

57. Lancaster M, Rouse J, Hunter KW: Modifiers of mammary tumor progression and metastasis on mouse chromosomes 7, 9, and 17. Mamm Genome 2005, 16:120-126.

58. Hundley JE, Koester SK, Troyer DA, Hilsenbeck SG, Barrington $\mathrm{RE}$, Windle JJ: Differential regulation of cell cycle characteristics and apoptosis in MMTV-myc and MMTV-ras mouse mammary tumors. Cancer Res 1997, 57:600-603.

59. Amundadottir LT, Johnson MD, Merlino G, Smith GH, Dickson RB: Synergistic interaction of transforming growth factor alpha and c-myc in mouse mammary and salivary gland tumorigenesis. Cell Growth Differ 1995, 6:737-748.

60. Sleeman JP, Cremers N: New concepts in breast cancer metastasis: tumor initiating cells and the microenvironment. Clin Exp Metastasis 2007, 24:707-715

61. Zhang M, Behbod F, Atkinson RL, Landis MD, Kittrell F, Edwards D, Medina D, Tsimelzon A, Hilsenbeck S, Green JE, Michalowska AM, Rosen JM: Identification of tumor-initiating cells in a p53 null mouse model of breast cancer. Cancer Res 2008, 68: 4674-4682.

62. Li F, Tiede B, Massague J, Kang Y: Beyond tumorigenesis: cancer stem cells in metastasis. Cell Res 2007, 17:3-14.

63. Glinsky GV, Berezovska O, Glinskii AB: Microarray analysis identifies a death-from-cancer signature predicting therapy failure in patients with multiple types of cancer. $J$ Clin Invest 2005, 115:1503-1521.

64. Molofsky AV, Pardal R, Iwashita T, Park IK, Clarke MF, Morrison $\mathrm{SJ}$ : Bmi-1 dependence distinguishes neural stem cell selfrenewal from progenitor proliferation. Nature 2003, 425:962967.

65. Liu S, Dontu G, Mantle ID, Patel S, Ahn NS, Jackson KW, Suri P, Wicha MS: Hedgehog signaling and Bmi-1 regulate selfrenewal of normal and malignant human mammary stem cells. Cancer Res 2006, 66:6063-6071.

66. Abate-Shen C, Brown PH, Colburn NH, Gerner EW, Green JE, Lipkin M, Nelson WG, Threadgill D: The untapped potential of genetically-engineered mouse models in chemoprevention research: opportunities and challenges. Cancer Prev Res 2008, 1:161-166.

67. Pegram MD, Konecny G, Slamon DJ: The molecular and cellular biology of HER2/neu gene amplification/overexpression and the clinical development of herceptin (trastuzumab) therapy for breast cancer. Cancer Treat Res 2000, 103:57-75.

68. Calogero RA, Musiani P, Forni G, Cavallo F: Towards a longlasting immune prevention of HER2 mammary carcinomas: directions from transgenic mice. Cell Cycle 2004, 3:704-706.

69. Bergers G, Javaherian K, Lo KM, Folkman J, Hanahan D: Effects of angiogenesis inhibitors on multistage carcinogenesis in mice. Science 1999, 284:808-812.

70. O'Reilly MS, Holmgren L, Shing Y, Chen C, Rosenthal RA, Moses M, Lane WS, Cao Y, Sage EH, Folkman J: Angiostatin: a novel angiogenesis inhibitor that mediates the suppression of metastases by a Lewis lung carcinoma. Cell 1994, 79:315328.

71. Moody SE, Sarkisian CJ, Hahn KT, Gunther EJ, Pickup S, Dugan KD, Innocent N, Cardiff RD, Schnall MD, Chodosh LA: Conditional activation of $\mathrm{Neu}$ in the mammary epithelium of transgenic mice results in reversible pulmonary metastasis. Cancer Cell 2002, 2:451-461.

72. Jones RA, Campbell Cl, Gunther EJ, Chodosh LA, Petrik JJ, Khokha R, Moorehead RA: Transgenic overexpression of IGF- 
IR disrupts mammary ductal morphogenesis and induces tumor formation. Oncogene 2007, 26:1636-1644.

73. Gunther EJ, Belka GK, Wertheim GB, Wang J, Hartman JL, Boxer $\mathrm{RB}$, Chodosh LA: A novel doxycycline-inducible system for the transgenic analysis of mammary gland biology. FASEB $J$ 2002, 16:283-292.

74. Gunther EJ, Moody SE, Belka GK, Hahn KT, Innocent N, Dugan $\mathrm{KD}$, Cardiff RD, Chodosh LA: Impact of p53 loss on reversal and recurrence of conditional Wnt-induced tumorigenesis. Genes Dev 2003, 17:488-501.

75. Boxer RB, Jang JW, Sintasath L, Chodosh LA: Lack of sustained regression of C-MYC-induced mammary adenocarcinomas following brief or prolonged MYC inactivation. Cancer Cell 2004, 6:577-586.

76. Jang JW, Boxer RB, Chodosh LA: Isoform-specific ras activation and oncogene dependence during MYC- and Wntinduced mammary tumorigenesis. Mol Cell Biol 2006, 26: 8109-8121.

77. Varticovski L, Hollingshead MG, Robles Al, Wu X, Cherry J, Munroe DJ, Lukes L, Anver MR, Carter JP, Borgel SD, Stotler H, Bonomi CA, Nunez NP, Hursting SD, Qiao W, Deng CX, Green JE, Hunter KW, Merlino G, Steeg PS, Wakefield LM, Barrett JC: Accelerated preclinical testing using transplanted tumors from genetically engineered mouse breast cancer models. Clin Cancer Res 2007, 13:2168-2177.

78. Hoadley KA, Weigman VJ, Fan C, Sawyer LR, He X, Troester MA, Sartor Cl, Rieger-House T, Bernard PS, Carey LA, Perou CM: EGFR associated expression profiles vary with breast tumor subtype. BMC Genomics 2007, 8:258.

79. Shibata MA, Kavanaugh C, Shibata E, Abe H, Nguyen P, Otsuki Y, Trepel JB, Green JE: Comparative effects of lovastatin on mammary and prostate oncogenesis in transgenic mouse models. Carcinogenesis 2003, 24:453-459.

80. Shibata MA, Akao Y, Shibata E, Nozawa Y, Ito T, Mishima S, Morimoto J, Otsuki Y: Vaticanol C, a novel resveratrol tetramer, reduces lymph node and lung metastases of mouse mammary carcinoma carrying p53 mutation. Cancer Chemother Pharmacol 2007, 60:681-691.

81. Li Y, Zhang $Y$, Hill J, Shen O, Kim HT, Xu X, Hilsenbeck SG, Bissonnette RP, Lamph WW, Brown PH: The Rexinoid LG100268 prevents the development of preinvasive and invasive estrogen receptor negative tumors in MMTV-erbB2 mice. Clin Cancer Res 2007, 13:6224-6231.

82. Li Y, Zhang Y, Hill J, Kim HT, Shen Q, Bissonnette RP, Lamph WW, Brown PH: The rexinoid, bexarotene, prevents the development of premalignant lesions in MMTV-erbB2 mice. $\mathrm{Br} J$ Cancer 2008, 98:1380-1388.

83. Banach-Petrosky W, Ouyang X, Gao H, Nader K, Ji Y, Suh N, DiPaola RS, Abate-Shen C: Vitamin D inhibits the formation of prostatic intraepithelial neoplasia in Nkx3.1; Pten mutant mice. Clin Cancer Res 2006, 12:5895-5901.

84. Kim HT, Kong G, Denardo D, Li Y, Uray I, Pal S, Mohsin S, Hilsenbeck SG, Bissonnette R, Lamph WW, Johnson K, Brown PH: Identification of biomarkers modulated by the rexinoid LGD1069 (bexarotene) in human breast cells using oligonucleotide arrays. Cancer Res 2006, 66:12009-12018.

85. Blenkiron C, Goldstein LD, Thorne NP, Spiteri I, Chin SF, Dunning MJ, Barbosa-Morais NL, Teschendorff AE, Green AR, Ellis IO, Tavaré S, Caldas C, Miska EA: MicroRNA expression profiling of human breast cancer identifies new markers of tumor subtype. Genome Biol 2007, 8:R214. 